\title{
Multidimensional Analysis for Agricultural Producers' Health Care in Cameroon
}

\author{
Jules Medard NANA DJOMO (Corresponding author) \\ The University of Yaounde-II \\ Facultyof Economic Sciences and Management \\ P.O. BOX 1365 Yaounde, Cameroon \\ Tel: 237-22-213-441Ｅ-mail: jdjomo81@yahoo.fr
}

\author{
FONDO SIKOD \\ The University of Yaounde-II \\ Economic Sciences and Management \\ P.O. BOX 1365 Yaounde, Cameroon \\ Tel: 237-22-213-441_E-mail: fsikod2002@yahoo.com
}

Received: January 27, 2012

Accepted: March 5, $2012 \quad$ Published: May 1, 2012
URL: http://dx.doi.org/10.5539/ijef.v4n5p124

doi:10.5539/ijef.v4n5p124

\begin{abstract}
This research evaluates farmers' demand for health care in Cameroon by measuring the degree of access to public health care and estimating health care demand factors'. The methodology involves Lorenz curves' construction, the use of Multiple Correspondence Analysis and the construction of health care's demand model. The database used to produce the results is the Third Cameroonian Household Survey conducted by the National Institute of Statistics. First results indicate that the poorest farmers have less access to public health structures than farmers who are better off. Then, the cost of consultation determines the choice of medical sector for farmers. Farmers who are better off cover less distance to attain medical services than those who are poor. To solve this problem of health care's difficult access for poorest farmers, policymakers should stimulate demand by costs' discriminatory policies in order to give more opportunities to these farmers to get access to public health care.
\end{abstract}

Keywords: Multidimensional analysis, Health care

\section{Introduction}

Health is a basic need. This explains the constant intervention and involvement of public authorities in the field of health. The health sector in most African countries has, since the last decade, a lack of more and more resources. The causes of this under-funding are likely exogenous and endogenous. The external causes are the result of the decrease in general revenues. Endogenous causes include mainly poor policy choices in resources' allocation and structural and managerial weaknesses. In almost all African states, known as the Bamako Initiative (note 1) has sometimes provoked strong reactions since its launching in 1987, particularly with regard to the possible economic exclusion of some people due to pricing and introduction of costs recovery from care users.

In developing countries, most people under the poverty line live in rural areas (World Bank, 1997). Malnutrition and health problems directly affect the ability to work, even in countries that have achieved a high level of economic development. These problems create a vicious circle of low productivity, low wages, malnutrition, diseases, and low work capacities. The World Health Organization (1999) argues that reducing the burden of the disease is its first priority, while a World Bank's (1997) report emphasizes the urgent need for cooperation with countries to reduce the impact of poverty on populations' conditions in terms of health and nutrition, and protect it from the effects of depletion of diseases, malnutrition and high fertility. The agricultural sector is particularly affected because the work remains largely manual or semi-mechanized and thus, closely related to physical capacities. The outdoor work exposes farmers to weather, cold, heat and sun. These factors can cause many problems which, if they don't get strictly into professional diseases' category will lead to absentee, lower productivity and reduce the body's resistance to diseases. Farmers are rarely protected by a system of recording and declaration and are not entitled to social 
security benefits unless they adhere to it voluntarily by paying their own contributions. Small health centers and field hospitals in Cameroon, can't offer the same services as the major hospitals of the cities for that attract and retain difficulty their hard staff (Forastieri, 2000). As a result, health status in rural areas is worse than urban centers. Some farm workers live in extremely primitive conditions, in areas where roads are missing or unsuited, making transportation difficult. To meet this challenge, it's appropriate to adopt a multidimensional approach to better understand the obstacles and defects that undermine the consumption of health care for farmers in Cameroon. The multidimensional approach permit to address more broadly but not exhaustive the problem that is to broaden the scope of research. Therefore, the objectives of this work are firstly, to proceed to factorial analysis of health care, secondly, to assess access to health care and finally, to assess health care demand determinants' for farmers in Cameroon's rural sector.

\section{Literature Review}

In Africa, implementation of health reforms' analysis in recent decades all point to the same conclusion: the fair aspect of public health policy has been neglected, and the primary concerns of the actors focused on the effectiveness of organization to set up (Gilson, 2000; Standing, 2002). Experiences in connection with the implementation of public policies in West Africa (Ridde, 2005), particularly in Burkina Faso (Nitièma and al., 2003; Haddad and al., 2004; Ridde and al., 2005), produce the same results. Thus, understanding the concept of equity, according to the viewpoint of stakeholders, is essential (Ridde, 2006). "In the analysis of efficiency or equity, in the reflection focused on the fight against poverty, the role of values is, of course, preeminent" (Sen, 2000). On the same continent, others have found that indeed the equity in the health care system has become a secondary goal giving priority to financial viability, effectiveness and efficiency (Leighton, 1996). However, equity is a polysemous term and is a concept whose content depends on both the epistemological position of the researcher and the social environment of actors studied (Peter, 2001; Braveman and Gruskin, 2003; Oliver and Mossialos, 2004). To understand the value placed on equity by the Cameroonian and commitment offering, it is essential to know the range of their conceptual definitions.

The concept of health as a very ordinary fully justifies that the distribution of health care is the result of free trade made in a market. Two arguments can be raised, one better suited to the analysis of Nozick (1988), the other to Hayek (1994) ones. Both combine to reject any public redistribution in health care. The market is the only procedure that guarantees respect for individual freedom. Everyone is entirely free to purchase care according to his preferences that is, according to the importance he attaches to his health, according to his attitude towards risk, etc (note 2). The second argument for care access in respect of market's laws relates to the effectiveness of this procedure. Set individual decisions leads to optimal resources' allocation. The Moderate liberalism has the particularity of accepting state's intervention. So the market remains the general rule for acquiring essential goods, partial support may be granted to individual beneficiaries for certain goods. In the contractarian theory of Buchanan (1986), the unjust inequalities are the inequalities of birth: the contractors of the constitutional contract would agree to consider that it's not fair that some people are disadvantaged when they start in life. Unlike at libertarians, the egalitarians admit that the good "health" has a particular value. They also go beyond the moderate Liberals by recognizing a guardian character, therefore justifying more extensive interventions. A first definition of equal access is provided by Le Grand (1982): two individuals have equal access to a good when they have to pay the same "price" for it. By price, we mean not only the monetary price which is in charge of the patient, but also more broadly the price in terms of distance and time. A second definition of equal access is provided by Olsen and Rogers (1991): two individuals have equal access to a good if and only if they can consume the same amount of this good.

Also, despite the speeches of recent decades, the poorest still lack access to health services. Primary health care affordable and accessible for all are essential for human development and a basic duty and of key importance for achieving the Millennium Development Goals (MDGs). A common problem in many Sub-Saharan African countries since the late 1980s is extreme poverty. According to World Bank's (2000) assessment, from 217.2 million people living with less than \$ 1 a day in sub-Saharan Africa in 1987, it rose to 290.9 million in 1998 that is an increase of $34 \%$ in 12 years. During this period, in South Asia, it increased from 474.4 to 522 million that is an increase of $10 \%$. In East Asia and Pacific region, poverty has declined more. The number of people living with less than $\$ 1$ a day felt from 452.4 million in 1990 to 265.1 million in 1996. In fact, for the UNDP (2001), the sub-Saharan Africa is lagging behind others: not only the income and human poverty remains considerable, but also, the adults' literacy rate there is still only 60 percent and life expectancy at birth stand on 48.8 years. Thus, sub-Saharan African countries are in their majority, countries with lowest Human Development Index (HDI); those who have medium HDI come at the end of list of these category countries.

Cameroon is among the countries with medium Human Development Index, with a HDI of 0.500, since the 1990s. The strong poverty reduction recorded during the period 1996-2001 has been replaced by a quasi-stability of income 
poverty between 2001 and 2007. The stability of the observed poverty at the national level masks a striking contrast between areas of residence. In urban areas, in fact, the poverty rate which was $17.9 \%$ in 2001 declined by 5.7 points over the period 2001- 2007, when he was quite up by3 points in the rural areas, and stand at $55.0 \%$ in 2007 (INS, 2008). The worsening of the situation observed in rural areas is partly explained by the fact that the earned income didn't increased at a sufficient rate to enable farmers to maintain their purchasing power. Indeed, the purchase price to producers has not evolved to enable farmers to maintain their living standards. Moreover, this is due to low yields and difficulties in selling their products at remunerative prices. The attention to equity dimension of health care is particularly important in Cameroon, due to widespread poverty. However, the economic transition process, heavily dependent on resource endowments, cash crops and food crops, livestock exports, and strong current of emigration to neighboring countries and hampered by a multitude of constraints, there is a very low level of human development and poverty sustainably.

\section{Methodology}

Here, we are going to first of all to dwell at length on data's' source before elaborating the methodology itself.

\subsection{Data Source}

The data used in this research are those from the Third Cameroonian Household Survey (ECAM III) which was conducted by the National Institute of Statistics (INS) in 2007.This is the most recent database on households in Cameroon. It provides a range of variables necessary to carry out this work because it covers the whole Cameroon and also, provides information on households' situation by sector and by place of residence. We have to underline that in this study, we are interested by agricultural households in rural sector that is households which heads of family activity is agriculture. It's also important to notice that the study stand on agricultural households and not on agricultural industries. The total size of investigated farm heads household is 4275 .

\subsection{Construction of Health Care Access Indicator}

Multidimensional analysis techniques also known as factor analysis are used to construct an indicator which weighting contained in the functional form of the indicator are less arbitrary. The main advantage of this method stand on the fact that it eliminates the assigning scores arbitrary nature. Thus, it leaves little room for subjectivity. This approach is called inertia approach because it comes from the static mechanics. It uses Multiple Correspondence Analysis (MCA) techniques in the case of individuals array characterized mainly by qualitative variables. The basic idea is to summarize the information provided by these qualitative indicators in just one composite index. In this work it is proposed to use a third variant of analysis factor, namely the MCA as suggested and presented by Asselin (2009). Two reasons for this choice: i) this method is more suitable to the nature of our data including a set of categorical variables presented below in the appendix and representing the different modalities that can take the primary indicators that reflect households' living conditions, ii) several studies on the measurement of living standards in Africa have been performed using this method: Ayadi and al. (2005) for Tunisia; $\mathrm{Ki}$ and al. (2005) for Senegal, Foko and al. (2007) for Cameroon. Analyses will be performed with the SPAD software. The variables are summarized in Table 4 in annex.

\subsection{Measurement of Equity in Public Health Care Access}

Public spending goal is in general to provide opportunities to the most disadvantaged groups and improve their social and economic position. It is important to know whether these expenditures are more or less directed towards these groups. It's to solve this problem that the well-being economic literature proposed two main approaches: the first focuses on the need to measure individual preferences for the goods in question based on microeconomic theory (Glewwe and Patrinos, 1998). This approach, however, requires too much data and implies a precise knowledge of individuals and households' demand functions; the second approach is the analysis of the impact of earnings (Demery and al., 1995). This method combines the analysis of requirements and expenditures required for the production of public services with information on accessing these services in order to deduce how the gains are distributed among individuals or households. It's based on the idea that households which get access to a public health center benefit from a subsidy to compensate for their lack of resources. It is also based on the assumption that the distribution of spending between socioeconomic groups depend on:

- The allocation of resources to and within the sector concerned, that is the average spending per user of the service;

- The level of access for different groups of household structures and services available to them that is access rates per socioeconomic group.

Concerning access to care, it's suitable to describe the inequality by the rate of care access, their cost, measured by personal care spending or health spending. Equality will be said perfect if the cumulative frequencies' curve merges 
with the first bisector ones. The inequality is proven if the cumulative frequencies' curve is faraway from the first bisector.

\subsection{Specification of Health Care Demand Equation}

The dependent variable HCD (health care demand) takes the following procedure: $1.00=$ public sector, $2.00=$ formal private sector and 3.00 = informal sector. The public sector includes: first class hospital, provincial hospital, district hospital, the medical center sub-division and the integrated health center. While the formal private sector includes: pharmacy, clinic / medical office and ICG / NGO health. Finally, the informal sector includes: traditional healers, informal vendors and other. The equation of health care demand is then presented as follows:

$$
H C D_{i}=\alpha_{0}+\alpha_{1} \text { headsex }_{i}+\alpha_{2} \text { headage }_{i}+\alpha_{3} \text { edulevel }_{i}+\alpha_{4} \cos t_{i}+\varepsilon_{i}
$$

Where headsex : producer head household's sex, headage: its age; edulevel: level of education and cost: the cost of consultation. $\varepsilon_{i}$ is the error term and $\alpha_{i}(\mathrm{i}=0,1,2,3,4)$ parameters to be estimated. The dependent variable is qualitative and having more than two unordered terms, equation [1] can be estimated only by the unordered multinomial logit. The multinomial logit model is a direct generalization of the logit model that can be used to treat any situation with three or more unordered qualitative responses. More detailed treatments are presented in the synthesis articles; see especially Greene (1990), among others.

\section{Empirical Results}

The results of the MCA are contained in Figure 1 in annex. These results indicate that farmers who are better off of the fifth quintile of the spending are located in the first quadrant. They are consulted in provincial hospitals usually located in the major regions of Cameroon. They bear the higher costs of consulting and choose the public, private, confessional and parapublic sectors for their need of consultation. These producers put forwards as reasons for choosing these areas of consultation: service quality and proximity. They are consulted by the doctor, health staff and the nurse. In addition, they cover the least distance to attain integrated health centers (IHC), district hospitals (DH) and pharmacies (PH). They therefore have the highest annual health spending. The main reasons for the consultation sector's choice are: The family decision and relationships. They are some of the visually impaired and speech disabilities. Some producers say that they have done the HIV's test and others accept to do it. Education levels of these producers are: higher level, secondary second cycle and secondary first cycle.

Agricultural producers have-nots of the second quadrant are consulted by the traditional healers and informal vendors of drugs. Customs and beliefs are the main reasons for the choice of the consultation sector. They have a low cost of consultation, but their health spending is higher. These producers suffer from malaria, diarrhea and respiratory diseases. Some of these producers are handicapped. Among the handicaps, we have the hearing impairment, motor, mental and other disabilities not specified. They cover quite long distance to attain district hospitals and pharmacies. Even though farmers of the third quadrant seem not to be concerned by the care demand during investigations because according to them, they don't know if they have been sick, they are however faraway from health services and pharmacies and therefore have the lowest health costs. They have never done the HIV test. While in the fourth quadrant, the producers say they are not sick and as result, answer don't know (DK) if they are suffering from malaria, respiratory diseases, diarrheal disease, get tested for HIV / AIDS and don't know the distances from their homes to health centers and pharmacies. However, in view of the graph, it's difficult to locate the men and women. But men are much more localized in the third quadrant of producers not knowing their health status while women belong more to the second quadrant of producers who reported having been ill and consulted.

Figure 2 in annex shows the percentage of access to care in public health facilities. The farmers have more access to health facilities integrated and the district hospitals. These public health facilities are those located in rural areas of Cameroon. While the medical center sub-division is in the heads of departments. In addition, hospitals of first class and provincial hospitals are respectively installed in towns especially, in the two major cities of Cameroon (Douala and Yaounde). It's therefore easy to understand why the poor farmers can't easily afford the care in these others public health centers.

The Lorenz curve in Figure 3 in annex shows that cumulative frequencies curve of health spending is below the total expenditures one: the proportion of this expenditure in total expenditure is low. In this perspective, the inequality in health spending is chronic, because the concentration area, the area between 0 and 1 , different curves and the 45 degrees straight line is great. The poorest farmers have a very insignificant level of health spending compared to the richest ones. It's important to underline that health expenditures include curative care expenditures, preventive care expenditures and others spending that contribute to improve health state. It's therefore possible to easily understand why the poorest farmers allocate just a bit of their spending to health demand. But in general, farmers in rural areas don't devote enough of their income to health care consumption. However, the yield curve of public health care 
access shows that access is inequitable between different social classes. Even though the area between the first bisector and the rates curve is small, farmers of the poorest households have however less access than farmers in the richest ones.

Figure 4 in annex shows the percentages of care demand in different areas of consultation. It appears that the public sector is the most area frequented by the farmers followed by the informal sector.

According to Table 1 in annex, in average, patients pay 4050 CFAF for consultation. The standard deviation of consultation cost is high, indicating a wide dispersion around the mean costs. At a minimum, some patients don't bear any consultation cost while others spend up to 99999 CFAF. The head of household's education level is a categorical variable: minimum $1.00=$ not schooled, $2.00=$ primary, $3.00=$ secondary 1 st cycle, $4.00=$ secondary 2nd cycle and the maximum $5.00=$ higher level. Also, the variable sex of producer is divided into: $1.00=$ male, 2.00 $=$ feminine. At a minimum, the producers have 15 years and at a maximum 99 years. However, the average age of household heads is 46 years.

The tests of likelihood ratios contained in Table 2 in annex show that all variables require a special analysis because they are all significant at $1 \%$.

The results in Table 3 in annex show that in the public sector, the consultation cost's parameter is significantly different to zero at the $1 \%$. It's therefore a significant variable in public sector care's demand. Because its parameter is zero, we then look at the odds ratio using the formula [Exp (B) - 1] * 100. It follows that a producer has a zero chance of being consulted in the public sector and a $100 \%$ probability of being consulted in the informal sector further to the increased of one unit of consultation's cost. The existence of informal sector is a palliative for the costs of seeking care. The poorest people will take an informal route treatment. Given not only the theoretical hypothesis put on the determinants of care's demand, but also on lessons learned by others applications in developing countries (Bitran and Mcinnes, 1986; Mwabu and al., 1993). It's first opportune to take into account economic factors that influence the key decision of an effective resort to patients' care. The age variable has a parameter significantly different to zero at the $1 \%$. By applying the above formula, a farmer has a $1.7 \%$ higher chance of being consulted in the public sector than in the informal sector if his age increases by one year. The age of the parents, as well as that of the individual patient may have a positive effect on households' decision of using health care. This is an approached variable of experience accumulation in health care (Barcat, 1998). The effect will be negative if the age is an indicator of senility, adults tiredness or obsolescence, inefficiency of the techniques learned (Bishai, 1996). The "not schooled" variable has a coefficient significantly different to zero at $1 \%$. A not schooled farmer has a probability of $90.8 \%$ lower to be consulted in the public sector compared to a farmer of higher level. Furthermore, the parameter of the modality "primary" is significantly different to zero at $5 \%$. Thus, a primary level farmer offers a 78\% probability less than the higher level farmer one for being consulted in a public sector. In addition, the modality "secondary first cycle" shows a coefficient significantly different to zero at $10 \%$. Thus, the probability for a farmer with secondary first cycle level to be consulted in the public sector is $72.3 \%$ less than a farmer with higher level one. In other words, not schooled farmers or primary and secondary levels ones are more likely to be consulted in the informal sector than the higher level farmers. Regarding the influence of education of the person responsible for the household, Schultz (1984) states that education has a direct impact on the acquisition of knowledge in health and hygiene domains. The gender variable has a coefficient significantly different to zero at $1 \%$. Thus, being male farmer offers $36.6 \%$ less chance to get access to public health care than being a female farmer.

In the formal private sector, the nullity of the cost consultation parameter indicates that an additional unit of consultation cost leads to a null chance of demanding for health care in the private sector, in the benefit of the informal sector. GoM's (2000a, 2000b) studies show that the demand for care in the formal sector highly depends on the household's living standards. The parameter of farmer's age variable indicates a positive effect in the health care demand in private sector. An additional year gives the opportunity to a farmer for being consulted in the private sector than in the informal sector. In the same logic, the negative signs of the parameters of each category of education level show a negative effect on care's demand in private sector. In other words, a not schooled farmer presents less chance to choose private sector for his consultation needs than a higher level farmer. Moreover, farmers with higher level have more chance to choose private health facilities than lower educational level ones. Kenkel (1994) shows that individuals with low incomes have also more often a low level of education. Anyway, people say they have renounced to care about financial reasons (Bocognano and al., 1999). Also, being male farmer decreases its ability for being consulted in private sector in benefit of informal sector.

\section{Conclusion}

The objective of this research was to assess the degree of accessibility and demand for health care of rural farmers in Cameroon. To achieve this goal, firstly, we quantified the equity of access to public health care. Secondly, we 
estimated the equation of health care demand. In addition, the Lorenz curves construction allowed us to classify farmers by living standards and degree of accessibility to public health care. While the multinomial logit method was used to estimate the equation demand in health care. The most convincing results were as follows:

The poorest farmers allocate just a bit of their spending on health care acquisition. One's notices that access to public health care services is unfavorable for the poorest farmers. Thus, only $6 \%$ of poorest farmers access to public health care against $14 \%$ for the richest ones. Proximity is the main reason for the choice of the public sector, but the consultation cost remains a concern for farmers. However, the cost of consultation appears to be the main reason for the choice of informal sector. Thus, in order for the public sector to attract farmers from informal sector, government should revise its policy of consultation costs fixing. In this perspective, it should adopt a discriminatory policy of consultation costs for the poorest farmers. This policy should be sustained by a policy of "bringing nearer" most distant farmers public health services.

Moreover, consultation cost is the main factor that negatively influences health care demand in the formal sectors. Thus, the additional unit of consultation cost involves farmers in the informal sector for their health needs. As consequence, a farmer has a null chance of being consulted in the public and formal private sector and a $100 \%$ probability of being consulted in the informal sector further to the increased in unit of consultation cost. However, a not schooled farmer has a less $90.8 \%$ probability for being consulted in the public sector than a higher level farmer. In the same way, a not schooled farmer presents less chance to choose the formal private sector for its consultation needs than a higher level farmer. This last result confirms the importance of education in health care application. The most educated farmers have probably been informed of the need for being consulted in the formal sectors. It was also agreed that most educated farmers have the highest levels of income necessary to guarantee their health care needs in formal sectors. In this regard, the Government should put in its social policy, education as a priority despite of the many constraints the state is facing.

The Cameroon, having reached the completion point of the initiative for heavily indebted poor countries benefit a greater scope for its economic policy in general and social policy in particular so, it's imperative to put access to health care at the forefront of its concerns. To achieve this, economic and structural changes must be driven, especially in the development of the medical sector not only because health strengthens the productive capacities and thus, raises the income, but also because Cameroon pursues the objectives of Millennium Development Goals which first objective is to halve extreme poverty and hunger by 2015. Improve agricultural performance in this context requires that we give more attention to programs which goal is to increase agricultural productivity and competitiveness. Such programs need to remove obstacles from health care access in the formal sectors, build complementarities between formal and informal medical sectors and continue the reform of the institutions necessary for medical sector's emergence. These goals are long-run fundamentals in the medical development in Cameroon.

\section{References}

Asselin, L. M. (2009). Analysis of Multidimensional Poverty: Theory and case studies, Springer. http://dx.doi.org/10.1007/978-1-4419-0843-8

Ayadi, M., Ben Hassine, A., \& Chtioui, N. (2005). Analyse multidimensionnelle de la pauvreté en Tunisie : Une approche par les ensembles flous. JMA 2005, Hammamet Tunisie.

Barcat, G. (1998). Education des femmes et santé de leurs enfants en Indonésie, Mémoire de DEA, CERDI, Université d'Auvergne, Faculté des sciences économiques de Clermont-Ferrand.

Bishai, D. (1996). Quality Time: How parents schooling affects child health through its interaction with child care time in Bangladesh. Health http://dx.doi.org/10.1002/(SICI)1099-1050(199609)5:5<383::AID-HEC225>3.0.CO;2-W

Bitran, R. A., \& Mcinnes, D. K. (1986). The demand for health care in Latin America, Economic Development Institut of World Bank, an EDI Seminar Paper. 46, p. 54.

Bocognano, A., Dumesnil, S., Frerot, L., Grandfils, N., Le Fur Ph, \& Sermet, C. (1999). Santé, soins et protection sociale en 1998 Enquête sur la santé et la protection sociale - France 1998,Série résultats, CREDES - Décembre $1999, n^{\circ} 1282$.

Braveman, P., \& Gruskin, S. (2003). Defining equity in health. Journal ofEpidemiology and Community Health, 57, 254-58.

Buchanan, J. (1986). Market, Liberty and State, Harvester Press. 
Demery, L., Chao, S., Bernier, R., \& Mehra, K. (1995). The Incidence of Social Spending in Ghana. PSD Discussion Paper Series 19704, Poverty and Social Policy Department, Washington D.C., World Bank.

Foko, B., Ndem, F., \& Tchakote, R. (2007). Pauvreté et inégalités des conditions de vie au Cameroun : une approche micro multidimensionnelle. Cahier de recherche PPMA.

Forastieri, V. (2000). Challenges in providing health and safety for agricultural workers in the XXI century, ILO Program on Safety and Health in Agriculture.

Gilson, L. (2000). Readdressing equity: the importance of ethical processes. In A. Mills, Reforming health sectors (pp. 103-122). London and New York, Kegan Paul International.

Glewwe, P., \& Patrinos, H. A. (1998). The role of the Private Sector in Education in Vietnam. Working Paper, No. 132, Washington, D.C. 30 pages.

GoM (Government of Mozambique). (2000a). Action Plan for the Reduction of Absolute Poverty. Maputo.

GoM (Government of Mozambique). (2000b). Interim Poverty Reduction Strategy. Maputo.

Greene, W. H. (1990). Econometric Analysis. New York, Macmillan.

Haddad, S., Nougtara, A., \& Ridde, V. (2004). Les inégalités d'accès aux services de santé et leurs déterminants au Burkina Faso. Santé, Société et Solidarité, 2, 199-210.

Hayek, F- A. (1994). La constitution de la liberté. Paris, Litec, trad. fr. de The constitution of liberty, 1960, Londres, Routledge \& Kegan.

Institut National de la Statistique (INS) (2008). Tendances, profil et déterminants de la pauvreté au Cameroun en 2007. Rapport de l'Enquête ECAM III, Yaoundé.

Kenkel, D. S. (1994). The demand for preventive medical care. Applied Economics, 26, 313-325. http://dx.doi.org/10.1080/00036849400000078

Ki, J. B., Faye, B., \& Faye, S. (2005). Pauvreté multidimensionnelle au Sénégal : approche non monétaire fondée sur les besoins de base. Rapport final, PR-PMMA 044, Réseau PEP.

Le Grand, J. (1982). The Strategy of Equity. Londre, George Allen and Unwin.

Leighton, C. (1996). Strategies for achieving health financing reform in Africa. World Development, 24, 1511-25. http://dx.doi.org/10.1016/0305-750X(96)00058-7

Mwabu, G. M., Ainsworth, M., \& Nyamete, A. (1993). Quality of medical care and choice of medical treatment in Kenya: An empirical analysis. The World Bank Africa Technical Department Human Resources and Poverty Division Technical Paper, 9, 36 p.

Nitièma, A., Ridde, V., \& Girard, J. E. (2003). L'efficacité des politiques publiques de santé dans un pays de l'Afrique de l'Ouest: le cas du Burkina Faso. International Political Science Review, 24(2), 237-56.

Nozick, R. (1988). Anarchie, Etat et Utopie. Paris, PUF trad. fr. de Anarchy State and Utopia, 1974, New-York Books Inc.

Oliver, A., \& Mossialos, E. (2004). Equity of access to health care: outlining the foundations for action. Journal Epidemiology Community Health, 58(8), 655-58. http://dx.doi.org/10.1136/jech.2003.017731

Olsen, E. O., \& Rogers, D. L. (1991). The Welfare Economics of Equal Access. Journal of Public Economics, 45, 91-105. http://dx.doi.org/10.1016/0047-2727(91)90049-8

Peter, F. (2001). Health equity and social justice. Journal Applied Philosophy, 18(2), 159-70. http://dx.doi.org/10.1111/1468-5930.00183

Programme des Nations Unies pour le Développement (PNUD). (2001). Mettre les nouvelles technologies au service du développement. Rapport sur le Développement Humain, De Boeck Université.

Ridde, V. (2005). Politiques publiques de santé et équité en Afrique de l'Ouest. Le cas de l'Initiative de Bamako au Burkina Faso. Thèse de Ph. D. Université Laval Québec, Canada. http://www.theses.ulaval.ca/2005/23020/23020.html.

Ridde, V. (2006). Quelques logiques d'acteurs pour comprendre les effets de la mise en œuvre d'une politique de santé au Burkina Faso. In G. Verna et F. Piron. Ethique des rapports nord-sud. Québec, Presses de l'Université Laval. 
Ridde, V., Nitièma, A., \& Dadjoari, M. (2005). Améliorer l'accessibilité des médicaments essentiels génériques aux populations d'une région sanitaire du Burkina Faso. Cahiers Santé, 15(3), 175-82.

Schultz, T. P. (1984). Studying the impact of household economic and community variables on child mortality. Population and Development Review, 10, 215-35. http://dx.doi.org/10.2307/2807962

Sen, A. (2000). Un nouveau modèle économique. Développement, justice, liberté. Paris, Odile Jacob.

Standing, H. (2002). An overview of changing agendas in health sector reforms. Reprod Health Matters, 10(20), 19-28. http://dx.doi.org/10.1016/S0968-8080(02)00089-7

World Bank. (1997). Sector strategy: health, nutrition and population. Washington, World Bank.

World Bank. (2000). Rapport sur le développement 2000/2001. Combattre la pauvreté. Paris, Editions Eska, 2001, XIV-381 p.

World Health Organization. (1999). The world heath report 1999: making a difference. Geneva, World Health Organization.

\section{Notes}

Note 1. Every individual makes a choice between these needs and defines its basket price based on various goods and the value that these preferences attribute them, and, ultimately, according to its budget constraint.

Note 2 . Which backbone is primary health care.

Table 1. The exogenous variables in the demand for health care

\begin{tabular}{llllll}
\hline Exogenous variables & Valid N & Mean & Standard deviation & Minimum & Maximum \\
\hline Sex of the producer & 4275 & 1.28 & .450 & 1.00 & 2.00 \\
Age of the producer & 4275 & 45.96 & 15.794 & 15 & 99 \\
Cost of consultation & 1787 & 4049.58 & 18375.344 & 0 & 99999 \\
Educational level of the producer & 4275 & 1.9413 & .95184 & 1.00 & 5.00 \\
\hline
\end{tabular}

Source: Results from the study.

Note: Valid $\mathrm{N}$ is the number of valid observations. With $1 \mathrm{USD}=500 \mathrm{CFAF}$.

Table 2. Tests of likelihood ratios of the demand for health care

\begin{tabular}{lllll}
\hline Effect & $\begin{array}{l}-2 \text { log-likelihood of reduced } \\
\text { model }\end{array}$ & Chi-square & degrees of freedom & Significance \\
\hline Constant & $2627.081^{\text {(a) }}$ & .000 & 0 &. \\
Cost of consultation & 2653.634 & 26.552 & 2 & .000 \\
Age & 2647.490 & 20.408 & 2 & .000 \\
Educational level & 2712.660 & 85.579 & 8 & .000 \\
Sex & 2645.665 & 18.584 & 2 & .000 \\
\hline
\end{tabular}

The chi-square statistic is the difference in -2 log-likelihoods between the final model and a reduced model. The reduced model is formed by omitting an effect of the final model. The hypothesis is zero if all the parameters of this effect are zero. (a) This reduced model is equivalent to the final model because omitting of effect does not increase the degrees of freedom.

Source: Results from the study. 
Table 3. Parameter estimates of the demand for health care

\begin{tabular}{|c|c|c|c|c|c|c|c|}
\hline \multicolumn{2}{|c|}{ Consultation sector $^{(\mathrm{a})}$} & \multirow{2}{*}{$\frac{\mathrm{B}}{2.024}$} & \multirow{2}{*}{$\begin{array}{l}\text { Erreur std. } \\
.768\end{array}$} & \multirow{2}{*}{$\begin{array}{l}\text { Wald } \\
6.955\end{array}$} & \multirow{2}{*}{$\begin{array}{l}\text { Degrees } \\
\text { freedom }\end{array}$} & \multirow{2}{*}{$\begin{array}{l}\text { Signif. } \\
.008\end{array}$} & \multirow[t]{2}{*}{$\operatorname{Exp}(B)$} \\
\hline Public & Constant & & & & & & \\
\hline & Cost of consultation & .000 & .000 & 10.486 & 1 & .001 & 1.000 \\
\hline & Age & .017 & .004 & 19.660 & 1 & .000 & 1.017 \\
\hline & Not schooling & -2.388 & .747 & 10.224 & 1 & .001 & .092 \\
\hline & Primary & -1.512 & .745 & 4.116 & 1 & .042 & .220 \\
\hline & Secondary $1^{\text {st }}$ cycle & -1.285 & .754 & 2.903 & 1 & .088 & .277 \\
\hline & Secondary $2^{\text {nd }}$ cycle & -.917 & .779 & 1.383 & 1 & .240 & .400 \\
\hline & Higher & $0^{(\mathrm{b})}$ & . & . & 0 & . & . \\
\hline & Masculine & -.456 & .123 & 13.742 & 1 & .000 & .634 \\
\hline & Feminine & $0^{(\mathrm{b})}$ &. & . & 0 &. &. \\
\hline \multirow[t]{10}{*}{ Private } & Constant & 1.290 & .857 & 2.268 & 1 & .132 & \\
\hline & Consultation cost & .000 & .000 & 6.525 & 1 & .011 & 1.000 \\
\hline & Age & .015 & .006 & 5.635 & 1 & .018 & 1.015 \\
\hline & Not schooling & -3.290 & .815 & 16.299 & 1 & .000 & .037 \\
\hline & Primary & -2.362 & .806 & 8.585 & 1 & .003 & .094 \\
\hline & Secondary $1^{\text {st }}$ cycle & -2.321 & .828 & 7.852 & 1 & .005 & .098 \\
\hline & Secondary $2^{\text {nd }}$ cycle & -1.695 & .865 & 3.839 & 1 & .050 & .184 \\
\hline & Higher & $0^{(\mathrm{b})}$ & . & . & 0 & . & . \\
\hline & Masculine & -.686 & .192 & 12.714 & 1 & .000 & .503 \\
\hline & Feminine & $0^{(\mathrm{b})}$ & . & . & 0 & . & . \\
\hline
\end{tabular}

Source: Results from the study.

Note: The reference modality is: $3.00=$ informal sector. (b) This parameter is reset to zero because it is redundant. Number of observations: 1 784. 
Table 4. List of attributes of the MCA

\begin{tabular}{|c|c|c|c|c|}
\hline Sex of producer & Is the victim of a & Main handicap & Ill during the last two & Had a consultation for this \\
\hline Masculine & handicap & Visual handicap & weeks & disease \\
\hline \multirow[t]{2}{*}{ Feminine } & Yes handicapped & Speech disability & Yes was sick & Yes was consulted \\
\hline & Not & Hearing impairment & Not been sick & No was not consulted \\
\hline \multirow{7}{*}{$\begin{array}{l}\text { At present attains at } \\
\text { malaria } \\
\text { Yes attains malaria } \\
\text { Not } \\
\text { Don't know if achieved of } \\
\text { malaria }\end{array}$} & & Mental disability & Don't know if was sick & \\
\hline & Appreciation of its & Motor disability & & Currently achieved by a \\
\hline & current health & Deaf-mute & Tranche of age & diarrheal illness \\
\hline & Good & Other handicaps & Under 30 & Yes achieved \\
\hline & Good enough & & $30-39$ years & Not \\
\hline & passable & & $40-49$ years & Don't Know if achieved \\
\hline & $\mathrm{Bad}$ & & 50 years and & diarrhea \\
\hline \multirow{17}{*}{$\begin{array}{l}\text { Person who has consulted } \\
\text { for the disease } \\
\text { Pharmacist } \\
\text { Doctor } \\
\text { Health personnel } \\
\text { Traditional practitioner } \\
\text { Seller informal } \\
\text { Other } \\
\text { HIV testing done } \\
\text { Yes tested for HIV / AIDS } \\
\text { Not tested for HIV / AIDS } \\
\text { DK if tested for HIV / S } \\
\text { Undeclared }\end{array}$} & Consultation sector & Main reason for choice & Type of structure chosen & Accept do / repeat test for \\
\hline & Public & the consultation sector & for the consultation & $H I V / A I D S$ \\
\hline & Parapublic & Acceptable cost & First class hospital & Yes accepted \\
\hline & Private secular & Proximity & Provincial hospital & does not accept \\
\hline & Private confessional & Family decision & District hospital & DK if accept \\
\hline & & Custom / belief & Medical Center & Undeclared \\
\hline & Currently achieved by a & Quality of service & sub-division & \\
\hline & respiratory illness & Relationship & Integrated Health Centre & Level of education of \\
\hline & Yes achieved of & Other & Pharmacy & producer \\
\hline & respiratory disease & & Clinical / medical office & Not schooling \\
\hline & Not & Quintile of per capita & School nurse & Primary \\
\hline & DK if achieved & expenditure & Home / visit of the doctor & Secondary 1 st cycle \\
\hline & respiratory disease & Poorest & To go to traditional & secondary 2 nd cycle \\
\hline & & Second class & practitioner & Higher \\
\hline & & Third class & ICG / NGO Health & \\
\hline & & Fourth Class & The seller informal & \\
\hline & & Richest & Other & \\
\hline \multirow{12}{*}{$\begin{array}{l}\text { Cost of consultation } \\
\text { Cost of 000-600 } \\
\text { Cost of 650-2 000 } \\
\text { Cost of } 2300-4700 \\
\text { Cost of } 5000-10000 \\
\text { Cost of } 10100- \\
99997 \\
\text { Cost DK }\end{array}$} & Distance district hospital & Distance Integrated & Distance from the & annual health expenditure \\
\hline & $(D H)$ & Health Centre (IHC) & pharmacy $(\mathrm{PH})$ & Health expenditure \\
\hline & Less than $500 \mathrm{~m}$ & Less than $500 \mathrm{~m}$ & PH less than $500 \mathrm{~m}$ & 0-19967 \\
\hline & Distance $1-4 \mathrm{~km}$ & Distance $1-4 \mathrm{~km}$ & Distance PH 1-4km & Health expenditure \\
\hline & Distance $5-10 \mathrm{~km}$ & 5-10km distance & Distance PH 5-10km & $20000-79987.66$ \\
\hline & Distance $11-15 \mathrm{~km}$ & Distance $11-15 \mathrm{~km}$ & Distance $11-15 \mathrm{~km}$ & Health expenditure \\
\hline & Distance $16-19 \mathrm{~km}$ & Distance $16-19 \mathrm{~km}$ & Distance $16-19 \mathrm{~km}$ & $80000-159900.99$ \\
\hline & DK Distance DH & DK Distance IHC & Distance $20-30 \mathrm{~km}$ & Health expenditure \\
\hline & & & Distance $32-40 \mathrm{~km}$ & $160000-595200$ \\
\hline & & & Distance $42-70 \mathrm{~km}$ & Health expenditure \\
\hline & & & Distance $72-90 \mathrm{~km}$ & $600000-3797477.14$ \\
\hline & & & Distance PH DK & \\
\hline
\end{tabular}

Source: Results from the study. 


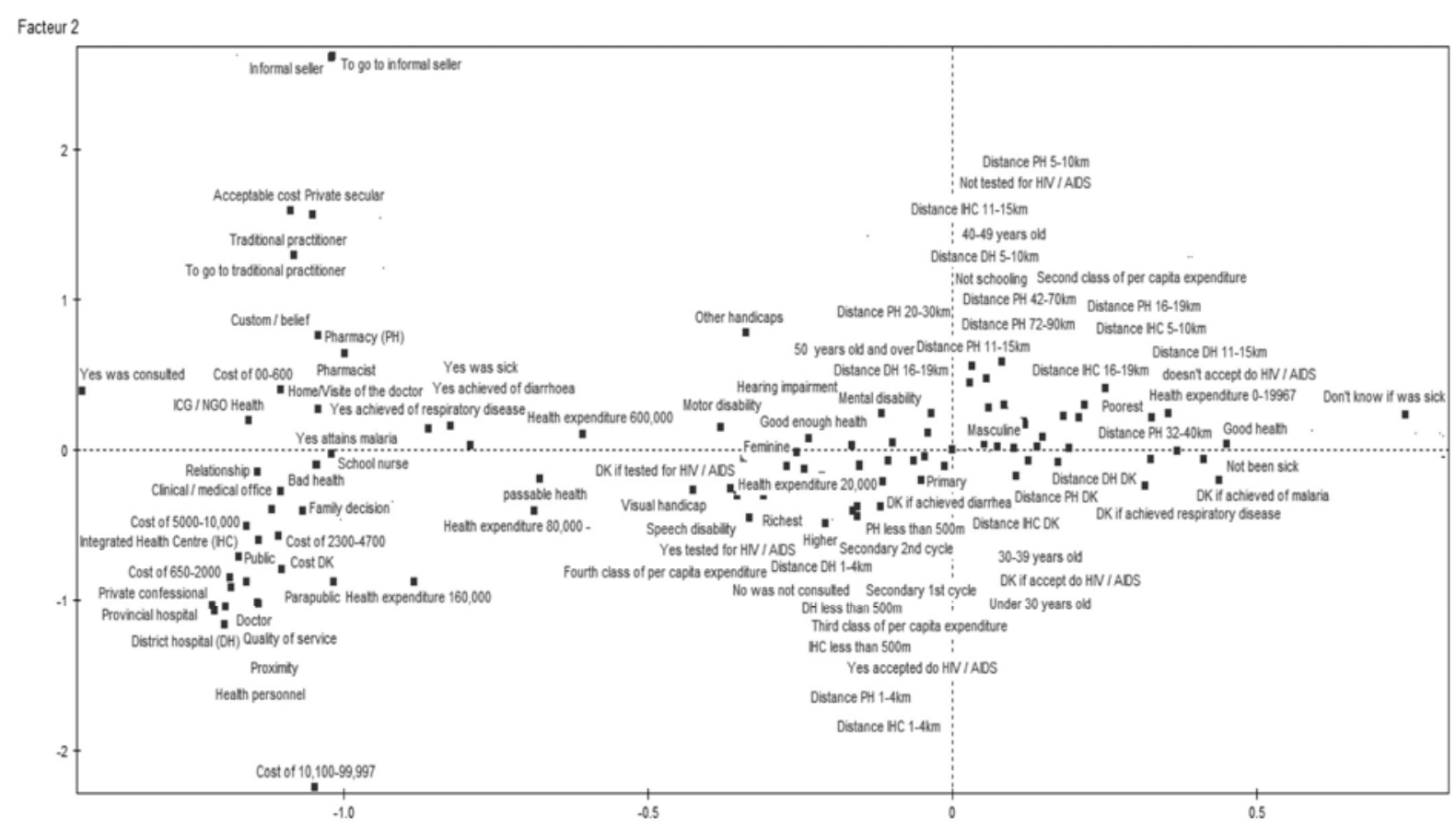

Figure 1. The MCA of access to health care

Source: Results from the study.

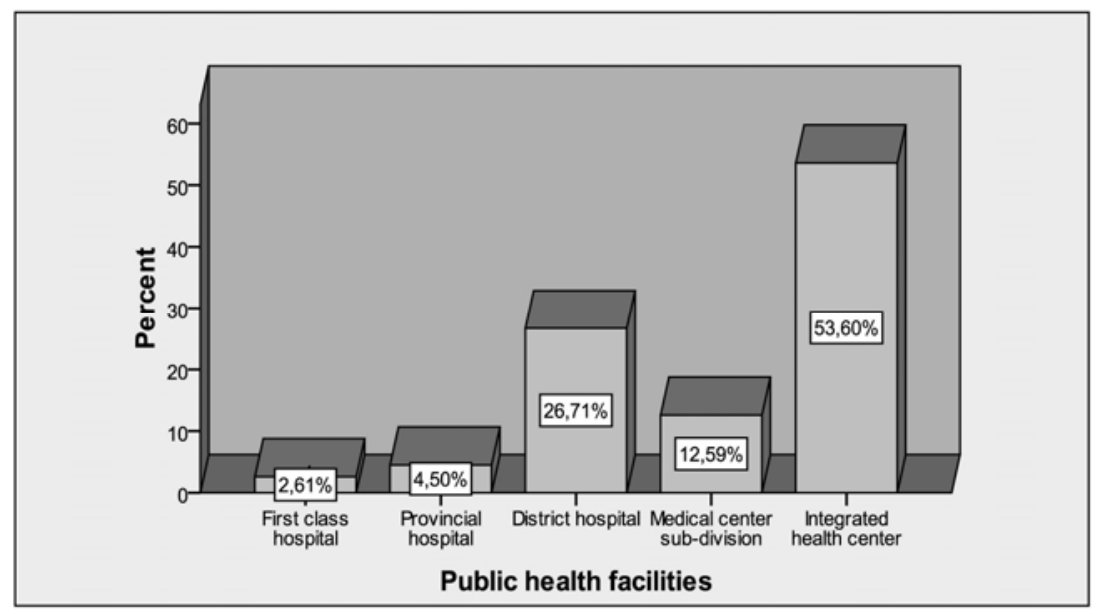

Figure 2. Percentage of health care access in public sector

Source: Results from the study. 


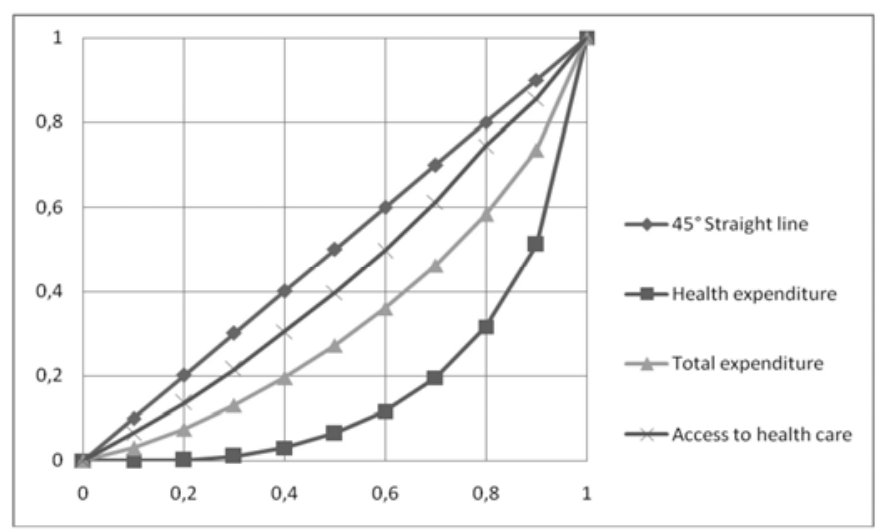

Figure 3. Lorenz curve of cumulative frequencies

Source: Results from the study.

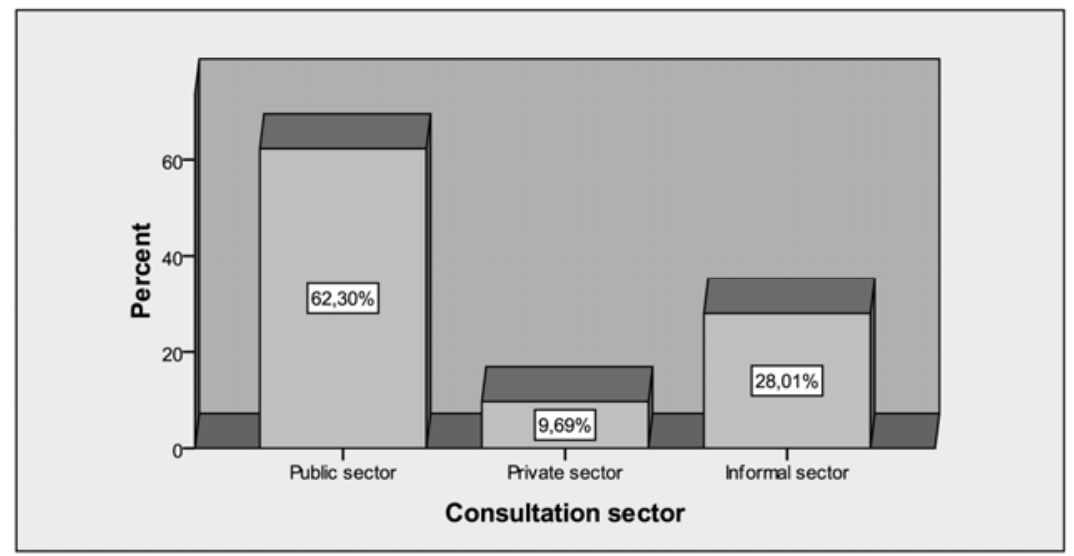

Figure 4. Statistics dependent variable's modalities

Source: Results from the study. 